\title{
Vitrectomy in 125 eyes with diabetic vitreous haemorrhage
}

\author{
GHOLAM A. PEYMAN, MOTILAL RAICHAND, FELIPE U. HUAMONTE, \\ KRISHAN C. NAGPAL, MORTON F. GOLDBERG, AND DONALD R. SANDERS \\ From the Department of Ophthalmology, University of Illinois \\ Eye and Ear Infirmary, Chicago
}

Vitreous haemorrhage has been one of the main causes of blindness in the diabetic patient. Before the advent of the new automated vitrectomy instruments, there was no effective treatment for this condition. Caird, Burditt, and Draper (1968) reported that $3 \mathrm{I}$ per cent of diabetic patients were registered blind within one year after the onset of vitreous bleeding. This report documents the visual outcome and surgical and postoperative complications in 125 eyes with diabetic vitreous haemorrhage.

\section{Methods}

A total of 125 eyes of 119 consecutive diabetic patients with vitreous haemorrhage of longer than six months' duration underwent pars plana vitrectomy. Their preoperative visual acuities ranged from perception of light to $20 / 400$. Sixty-seven eyes had simple diabetic vitreous haemorrhage, 48 eyes had tractional retinal detachment in addition to vitreous haemorrhage, and five eyes demonstrated rubeosis iridis and vitreous haemorrhage. Five eyes had all three conditions. All patients had proliferative diabetic retinopathy, which was known preoperatively or became evident upon clearing the haemorrhage. Preoperatively all patients underwent complete physical examination, with particular attention to their diabetic management, and a complete ocular examination with emphasis on visual acuity (including entoptic phenomenon, 2-point discrimination and light projection in those patients with less visual acuity than hand movements), presence of rubeosis iridis, applanation tensions, and presence of lenticular opacities.

In cases with vitreous opacification precluding adequate fundus examination, ultrasonography and, in selected cases, bright-flash electroretinography were performed.

The surgical techniques and instrumentation have been described previously (Peyman, Huamonte, and Goldberg, 1975; Peyman and Sanders, 1975). In more than 95 per cent of cases these were performed under local anaesthesia; their follow-up period ranged from six months to two years. In all cases the operative notes and operative complications were recorded by the

Address for reprints: Gholam A. Peyman, MD, University of Illinois Eye and Ear Infirmary, 1855 W. Taylor Street, Chicago, Illinois 60612, USA operative assistant, and the data were collected by two independent observers (MR and $\mathrm{KN}$ ).

\section{Results}

\section{VISUAL ACUITY}

Visual outcome has been assessed by the PeymanSanders' classification of visual improvement after vitrectomy (Figure) (Table I) (Peyman and Sanders, 1975; Peyman, Huamonte, and Goldberg, 1976). Those eyes with simple vitreous haemorrhage had the most favourable visual outcome; 72 per cent had some visual improvement. The five eyes that had vitreous haemorrhage with tractional retinal detachment and rubeosis iridis did poorly with none showing improvement and two with worsened visual acuity.

Table II summarizes visual outcome based on the type of procedure performed.

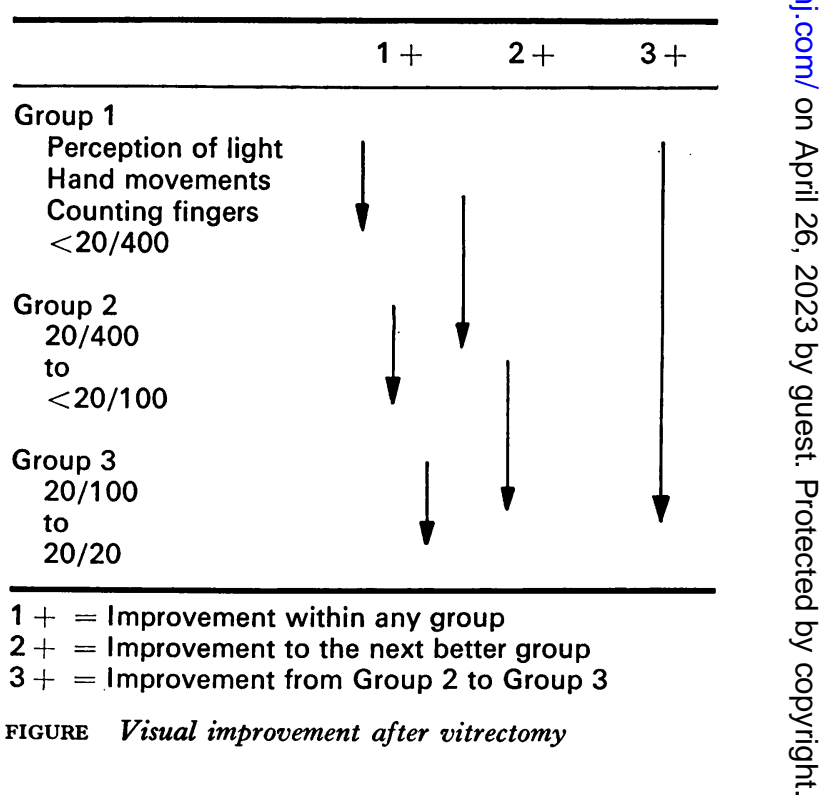


Table I Diagnoses and improvement in visual acuity

\begin{tabular}{|c|c|c|c|c|c|c|}
\hline \multirow{2}{*}{ Diagnoses } & \multirow{2}{*}{$\begin{array}{l}\text { No. of } \\
\text { eyes }\end{array}$} & \multicolumn{5}{|c|}{ Improvement in visual acuity* } \\
\hline & & $3+$ & $2+$ & $\mathbf{r}+$ & Same & Worse \\
\hline Vitreous haemorrhage & 67 & $\begin{array}{c}6 \\
(9)\end{array}$ & $\begin{array}{c}14 \\
(21)\end{array}$ & $\begin{array}{c}28 \\
(42)\end{array}$ & $\begin{array}{c}14 \\
(21)\end{array}$ & $\begin{array}{c}5 \\
(7)\end{array}$ \\
\hline $\begin{array}{l}\text { Vitreous haemorrhage, } \\
\text { tractional retinal } \\
\text { detachment }\end{array}$ & 48 & $\begin{array}{c}2 \\
(4)\end{array}$ & $\begin{array}{c}8 \\
(17)\end{array}$ & $\begin{array}{c}23 \\
(48)\end{array}$ & $\begin{array}{c}10 \\
(21)\end{array}$ & $\begin{array}{c}5 \\
(10)\end{array}$ \\
\hline $\begin{array}{l}\text { Vitreous haemorrhage, } \\
\text { rubeosis iridis }\end{array}$ & 5 & $\begin{array}{c}2 \\
(40)\end{array}$ & $\circ$ & 0 & $\begin{array}{c}3 \\
(6 \circ)\end{array}$ & $\circ$ \\
\hline $\begin{array}{l}\text { Vitreous haemorrhage, } \\
\text { tractional retinal } \\
\text { detachment, rubeosis } \\
\text { iridis }\end{array}$ & 5 & $\circ$ & $\circ$ & $\circ$ & $\begin{array}{c}3 \\
(60)\end{array}$ & $\begin{array}{c}2 \\
\left(4^{\circ}\right)\end{array}$ \\
\hline Total & 125 & $\begin{array}{l}\text { IO } \\
(8)\end{array}$ & $\begin{array}{c}22 \\
(17)\end{array}$ & $\begin{array}{c}5 \mathrm{I} \\
(4 \mathrm{I})\end{array}$ & $\begin{array}{c}30 \\
(24)\end{array}$ & $\begin{array}{c}12 \\
\text { (10) }\end{array}$ \\
\hline
\end{tabular}

*Peyman-Sanders' classification (1975)

Percentages are given in parentheses

Table II Surgical procedure and improvement in visual acuity

\begin{tabular}{|c|c|c|c|c|c|c|}
\hline \multirow{2}{*}{ Surgical procedure } & \multirow{2}{*}{$\begin{array}{l}\text { No. of } \\
\text { eyes }\end{array}$} & \multicolumn{5}{|c|}{ Improvement in visual acuity* } \\
\hline & & $3+$ & $2+$ & $\mathbf{I}+$ & Same & Worse \\
\hline Pars plana vitrectomy & 55 & $\begin{array}{c}4 \\
(7)\end{array}$ & $\begin{array}{c}10 \\
\text { (18) }\end{array}$ & $\begin{array}{c}17 \\
(3 \mathrm{I})\end{array}$ & $\begin{array}{c}18 \\
(33)\end{array}$ & $\begin{array}{c}6 \\
(11)\end{array}$ \\
\hline $\begin{array}{l}\text { Pars plana vitrectomy } \\
\text { and pars plana } \\
\text { lensectomy }\end{array}$ & 54 & $\begin{array}{c}6 \\
(\mathrm{I} I)\end{array}$ & $\begin{array}{c}9 \\
(17)\end{array}$ & $\begin{array}{c}25 \\
(46)\end{array}$ & $\begin{array}{c}1 \text { I } \\
(20)\end{array}$ & $\begin{array}{c}3 \\
(6)\end{array}$ \\
\hline $\begin{array}{l}\text { Clear corneal lens } \\
\text { extraction, and pars } \\
\text { plana vitrectomy }\end{array}$ & 16 & $\circ$ & $\begin{array}{c}3 \\
\text { (19) }\end{array}$ & $\begin{array}{c}9 \\
(56)\end{array}$ & $\begin{array}{c}2 \\
(12)\end{array}$ & $\begin{array}{c}2 \\
(12)\end{array}$ \\
\hline Total & 125 & $\begin{array}{l}\text { IO } \\
(8)\end{array}$ & $\begin{array}{c}22 \\
\text { (17) }\end{array}$ & $\begin{array}{c}51 \\
(4 I)\end{array}$ & $\begin{array}{c}3 \mathrm{I} \\
(25)\end{array}$ & $\begin{array}{l}\text { I I } \\
\text { (9) }\end{array}$ \\
\hline
\end{tabular}

*Peyman-Saunders' classification (1975)

Percentages are given in parentheses

\section{OPERATIVE AND POSTOPERATIVE COMPLICATIONS}

Table III itemizes the complications encountered in these eyes grouped according to whether tractional detachment and rubeosis iridis were present.

The major operative complication was bleeding from iris vessels and intravitreal fibrovascular stalks, which stopped by increasing the intraocular pressure or, rarely, by using intraocular diathermy. Two small retinal tears produced with the vitrophage were adequately treated with cryocoagulation and a buckling procedure. No retinal dialysis occurred.

The most common early postoperative complica- tion was corneal haze or striate keratopathy (7I per cent) which cleared in most cases. Thirty per cent of cases demonstrated a transient increase in intraocular pressure. One case of bacterial endophthalmitis occurred when the operating room personnel neglected to add $4 \mu \mathrm{g} / \mathrm{ml}$ of gentamicin to the vitrectomy infusion fluid, which is our standard prophylaxis. This eye subsequently required evisceration (May and Peyman, 1976).

The most common late complications after vitrectomy were persistent corneal oedema (I I per cent), repeated vitreous haemorrhage ( 13 per cent), and hyphaema ( 9 per cent). Six per cent of eyes had a persistent increase in intraocular pressure refractory to medical and surgical management at the time of last examination. Seven of eight eyes with clear lenses before vitrectomy developed posterior subcapsular cataracts sufficient to impair vision significantly. The rest of the patients in this series were aphakic after pars plana surgery. Five per cent of patients developed rubeosis iridis not noted preoperatively, and 3 per cent developed phthisis bulbi. In two cases, rhegmatogenous retinal detachment developed with holes thought to be unrelated to vitreous surgery, and in four cases preexisting tractional detachments worsened without evidence of hole formation.

\section{Discussion}

In our series, all patients undergoing vitrectomy met the criteria for their being registered as blind. After surgery, 25 per cent no longer were blind. An additional 40 per cent were improved, allowing most of them to function in familiar surroundings.

The major intraoperative and postoperative complication was bleeding related to neovascular tissue. Significant surgical complications related to intraocular manipulation such as retinal dialysis were notably absent. Postoperative transient and persistent corneal disorders may in part reflect the sensitivity of diabetic tissue to surgical trauma or inflammation.

We consider the complication rate acceptably low for the degree of improvement in visual acuity obtained and in view of the untreated natural course of this disease.

\section{Summary}

A total of 125 consecutive eyes, all registered blind with diabetic vitreous haemorrhage, underwent pars plana vitrectomy with the vitrophage. Sixty-six per cent experienced some improvement in their visual acuity; 24 per cent were unchanged and ro per cent were worse postoperatively. The major surgical complication was controllable haemorrhage (23 per cent). No retinal dialysis occurred. Significant 
Table III Complications

Diagnoses

Complication

No. of eyes

with complications

Surgical

Bleeding with spontaneous clearing

Bleeding with clearing after lavage or diathermy

Retinal tears

Lens particles in vitreous

Early postoperative (within 2 weeks)

Transient corneal oedema/striae

Transient rise in intraocular pressure

Repeated vitreous haemorrhage

Hyphaema

Endophthalmitis

Haemolytic glaucoma

Late postoperative (after 2 weeks)

Persistent corneal oedema/bullous keratopathy

Persistent rise in intraocular pressure

Repeated vitreous haemorrhage

Hyphaema

Cataract

Rubeosis iridis

Phthisis bulbi

Retinal detachment

\begin{tabular}{|c|c|c|c|}
\hline $\begin{array}{l}\text { Vitreous } \\
\text { haemorrhage }\end{array}$ & $\begin{array}{l}\text { Vitreous } \\
\text { haemorrhage, } \\
\text { tractional } \\
\text { retinal } \\
\text { detachment }\end{array}$ & $\begin{array}{l}\text { Vitreous } \\
\text { haemorrhage, } \\
\text { rubeosis iridis }\end{array}$ & $\begin{array}{l}\text { Vitreous } \\
\text { haemorrhage, } \\
\text { tractional } \\
\text { retinal } \\
\text { detachment, } \\
\text { rubeosis iridis }\end{array}$ \\
\hline 67 & 48 & 5 & 5 \\
\hline $\begin{array}{c}57 \\
(85)\end{array}$ & $\begin{array}{c}42 \\
(88)\end{array}$ & $\begin{array}{c}5 \\
(100)\end{array}$ & $\begin{array}{c}5 \\
(100)\end{array}$ \\
\hline
\end{tabular}

23

(18)

6

(5)

(2)

5

(4)

9
$(13)$

2

(3)

(I)

2

(3)

\begin{tabular}{cc}
89 & 52 \\
$(71)$ & $(78)$ \\
38 & 20 \\
$(30)$ & $(30)$ \\
10 & 4 \\
$(8)$ & $(6)$ \\
8 & 6 \\
$(6)$ & $(9)$ \\
1 & 1 \\
$(1)$ & $(1)$ \\
10 & 7 \\
$(8)$ & $(10)$ \\
\hline
\end{tabular}

27

(56)

IO
(20)

5

(I0)

(2)

o

o

(2)

3
$(6)$

(21)

4
$(8)$

I

(6)

6)


postoperative complications were transient (7I per cent) and persistent (I I per cent) corneal oedema, early ( 8 per cent) and late ( 3 per cent) vitreous haemorrhage, transient ( 30 per cent) and persistent (6 per cent) rise in intraocular pressure, and rubeosis iridis ( 5 per cent).

\section{References}

CAIRD, F. I., BURDITT, A. F., and DRAPER, G. J. (1968) Diabetes, I7/3, 121

MAY, D. R., and PEYMAN, G. A. (1976) Amer. F. Ophthal., 8r, 520

PEYMAN, G. A., HUAMONTE, F. U., and GOLDBERG, M. F. (1975) Ibid., 80, 30 , and - (1976) Ibid., 8r, 263

, and SANDERS, D. R. (1975) 'Advances in Uveal Surgery, Vitreous Surgery, and the Treatment of

Endophthalmitis'. Appleton-Century-Crofts, New York 